\title{
Penerapan Prinsip Terbaik Untuk Anak (The Best Interest of The Child) dalam Pemenuhan Hak Anak di Lembaga Pembinaan Khusus Anak
}

\author{
Agus Darwanta \\ Pengadilan Negeri Jakarta Utara \\ agusdarwanta@yahoo.com
}

\begin{abstract}
Abstrak
Hukum sebagai sarana pembinaan sangat dibutuhkan dalam pemenuhan perlindungan hukum terhadap anak yang berhadapan dengan hukum, anak yang berkonflik dengan hukum, dan anak sebagai korban tindak pidana. Pembinaan terhadap anak didik pemasyarakat di Lembaga Pembinaan Khusus Anak seharusnya dijadikan perhatian bagi Pemerintah Indonesia karena kondisi yang ditemukan pada tahap pasca adjudikasi, anak didik pemasyarakat yang ditempatkan di Lembaga Pembinaan Khusus Anak sangat memprihatinkan. Indonesia menjamin hak asasi setiap warga negaranya dalam konstitusi, termasuk jaminan dan perlindungan atas hak anak sebagai bagian dari hak asasi manusia. Rumusan masalah bagaimana penerapan prinsip terbaik untuk anak dalam pemenuhan hak anak di lembaga pembinaan khusus anak? Tujuan penelitian yaitu menganalisa penerapan prinsip terbaik untuk anak dalam pemenuhan hak anak di lembaga pembinaan khusus anak. Kegunaan penelitian dapat memberikan informasi kepada Lembaga Pembinaan Khusus Anak tentang penerapan prinsip terbaik untuk anak dalam pemenuhan hak anak. Metode Penelitian yang digunakan yuridis-normatif. Hasil menunjukan bahwa salah satu ciri prnsip terbaik untuk anak tercermin dalam diwajibkannya pendidikan bagi anak yang berkonflik dengan hukum dalam LPKA baik pendidikan formal maupun pendidikan informal sehingga hak pendidikan terpenuhi. Kesimpulan bahwa penerapan perlindungan anak yang berkonflik dengan hukum dengan menggunakan prinsip terbaik untuk anak di LPKA belum dilaksanakan secara optimal karena LPKA belum semuanya melaksanakan program pembinaan secara efektif dan efisien serta sesuai dengan peraturan perundang-undangan yang berkaitan dengan anak yang berkonflik dengan hukum.
\end{abstract}

Kata Kunci: Penerapan, prinsip terbaik, pemenuhan hak anak.

\section{The Application of The Best Interest of The Child Principle on The Fulfillment of Children's Rights in Children Penitentiary}

\begin{abstract}
Law as a means of fostering is urgently needed in fulfilling legal protection for children who are dealing with the law, children who are in conflict with the law, and children as victims of criminal acts. Guidance for communitybased pupils at the Special Guidance Institution for Children should be a concern for the Government of Indonesia because of the conditions found in the post-adjudication stage, community-based students who are placed in Special Guidance Institutions for Children are very alarming. Indonesia guarantees the rights of every citizen in the constitution, including the guarantee and protection of children's rights as part of human rights.
\end{abstract}


Formulation of the problem how to apply the best principles for children in the fulfillment of children's rights in special development institutions for children? The purpose of this research is to analyze the application of the best principles for children in fulfilling children's rights in special children's development institutions. The usefulness of research can provide information to the Institute for Special Development of Children about the application of the best principles for children in fulfilling children's rights. The research method used is juridical-normative. The results show that. The results of the study are one of the best prnsip characteristics for children reflected in the mandatory education of children in conflict with the law in LPKA both formal and informal education so that the right to education is fulfilled. Conclusion that the application of child protection in conflict with the law by using the best principles for children in LPKA has not been implemented optimally because LPKA has not all carried out coaching programs effectively and efficiently and in accordance with laws and regulations relating to children in conflict with the law. Conclusion

Keywords: Application, the best principle, fulfillment of children's rights.

\section{Pendahuluan}

Anak merupakan titipan Illahi yang perlu dibimbing agar menjadi manusia yang berguna bagi bangsa, negara, masyarakat, dan keluarga. Indonesia dengan konstitusinya yaitu UUD 1945 dalam Pasal 28B ayat (2) merumuskan tentang pemenuhan hak anak. Anak memiliki hak untuk tumbuh dan berkembang serta perlindungan. Karena anak dengan usianya masih relatif kecil dan di era teknologi serta jaman keterbukaan, maka perlu perlindungan dari kekerasan dan diskriminasi. (Peter Newel \& I Dewa Made, 25:2017)

Ketentuan dasar yang mengatur tentang pemenuhuan hak anak selain UUD 1945, juga telah diatur dalam Convention on the Rights of the Child atau Konvensi Hak Anak khususnya dalam Pasal 2 ayat (1), Konvensi diratifikasi oleh pemerintah Indonesia yaitu disahkan melalui Kepres No, 36 Tahun 1990 tentang Hak-Hak Anak. Selain itu diatur pula dalam UU No. 39 Tahun 1999 tentang Hak Asasi Manusia, UU No. 23 tahun 2002 tentang Perlindungan Anak, UU No. 35 tahun 2014 tentang Perubahan atas UU No. 23 tahun 2002, UU No. 13 Tahun 2006 tentang Perlindungan Saksi dan Korban, UU No. 21 Tahun 2007 tentang Pemberantasan Tindak Pidana Perdagangan Orang, serta UU No. 11 Tahun 2012 tentang Sistem Peradilan Pidana Anak. 
Komisi Perlindungan Anak Indonesia (KPAI) 1.434 pengaduan kasus anak berhadapan dengan hukum tahun 2018 meningkat dari pada tahun 2017 berjumlah 1.403 kasus. Hasil penelitian dari KPAI di 15 Lapas anak di Indonesia bahwa faktor pendorong perbuatan kejahatan tersebut adalah pergaulan bebas yang berlebihan dan media social yang mengarah pada tontonan pornografi (Devina Halim, Kompas: Kasus Anak Berhadapan dengan Hukum Tertinggi, Didominasi Kejahatan Seksual)

Pemicu terjadinya tindak pidana dikalangan atau melibatkan anak, hal ini disebabkan diantaranya oleh perkembangan teknologi, dimana saat ini begitu pesat sehingga tidak hanya dikalangan anak namun juga dikalangan orang-orang dewasa bahkan anak yang masih balita. Dan hal ini tentunya dapat memberikan pengaruh terhadap perilaku maupun kehidupan bersosial, sehingga kriminalpun tidak bisa dihindari. Oleh sebab itu perlu upaya penanganan dan upaya penyelesaian tanpa mengurangi atau mengabaikan hak anak.

Dalam hukum jika anak terlibat dalam kasus hukum, maka ini dimaknai anak dengan istilah anak berkonflik dengan hukum. Penanganan permasalahan anak yang berkonflik dengan hukum, sebagaimana yang dilaporkan Badan Pembinaan Hukum Nasional, dalam "Laporan Akhir Pengkajian Hukum Tentang Model Pembinaan Anak Berbasis Pendidikan Layak Anak Dalam Sistem Pemasyarakatan" bisa ditinjau dari tiga tahap, yaitu tahap pra-adjudikasi, adjudikasi dan pasca-adjudikasi. Pada tahap pra-adjudikasi, masalah yang dihadapi antara lain minimnya upaya diversi pada tahap awal proses peradilan pidana, tidak adanya rumah tahanan khusus anak yang mengakibatkan percampuran antara tahanan anak dan tahanan dewasa, belum terpenuhinya hakhak dasar anak seperti kualitas makanan, pendidikan, standar kesehatan, sanitasi dan sebagainya. Pada tahap adjudikasi, masalah yang dihadapi antara lain anak dengan kasus ringan maupun berat, tetap diproses sampai ke pengadilan, minimnya putusan non penjara. Pada tahap pasca-adjudikasi, masalah yang dihadapi antara lain di beberapa daerah di Indonesia, jumlah dan kondisi penjara khusus anak belum memadai, bahkan seringkali anak-anak disatukan dengan narapidana dewasa”. Keberadaan anak di Lapas dewasa lebih rentan terpengaruh 
lingkungan dan pola perilaku orang dewasa. Umumnya anak yang ditempatkan di Lapas dewasa hamper tidak mengikuti kegiatan pendidikan, kalua ada yang mengikuti sangat tidak optimal, karena harus berbagi perhatian dan fasilitas dengan warga binaan dewasa. (Nurini Aprialiani, 2014). Hal ini akan menimbulkan kerentanan terhadap pelanggaran hak sebagai anak didik dan sebagai anak, belum terpenuhinya dengan baik hak-hak anak didik pemasyarakatan, seperti kualitas makanan, pendidikan, standar kesehatan, ibadah, rekreasi, kunjungan dan lainnya.

Kondisi tersebut di atas tentunya sangat memprihatinkan karena anak adalah generasi penerus bangsa dan membutuhkan perlindungan hukum terhadap anak yang berkonflik dengan hukum sebagai persoalan yang harus mendapatkan perhatian yang serius bagi pemerintah dalam memenuhi perlindungan kepada anak tersebut. Oleh karena pemerintah dalam ragka memberikan perlindungan kepada anak yang berkonplik dengan hukum , maka disyahkan UU No. 12 tahun 1995 Tentang Lembaga Pemasyarakatan. Berdasarkan peraturan tersebut, maka Lembaga inilah yang mempunyai kewajiban untuk melaksanakan pembinaan terhadap narapidana dan anak didik pemasyarakatan, hal ini sebagai mana dalam Pasal 1 angka 3. Adapun penjelasan tentang Lembaga pemasyarakatan, warga binaan, dan anak didik dapat dilihat dalam Pasal 1 angka 5.

Dalam Pasal 1 angka 3 dan 5 tersebut di atas, dapat disimpulkan bahwa Lembaga pemasyarakatan ini merupakan bagian dari sistem pemasyarakatan, dengan tujuan memberikan perlindungan dalam bentuk memberikan binaan kepada narapidana dan anak didik pemasyarakatan agar menjadi manusia yang memiliki baik jasmani dan rohani, sehingga tidak mengulangi perbuatan yang melawn hukum. Dengan demikian diharapkan dapat diterima kembali oleh lingkungan di dalam masyarakat dimana mereka berada.

Selain UU Lembaga Pemasyarakat, Indonesia sebagai suatu negara yang bersungguh-sungguh dalam menjunjung dan menghormati hak asasi manusia, maka diatur juga di dalam UU Hak Asasi Manusia. Pada bagian kesepuluh dari 
Undang-Undang tersebut berisi tentang hak-hak anak, terutama hak anak tentang pendidikan, termuat pada Pasal 60 ayat 1, disebutkan bahwa:

"Setiap anak berhak memperoleh pendidikan dan pengajaran dalam rangka pengembangan pribadinya sesuai dengan minat, bakat, dan tingkat kecerdasannya".

Pendidikan dalam pandangan yang dikemukakan oleh Lengeveld dikutip dari Ary H Gunawan dijelaskan sebagai suatu proses mendewasakan anak, maka pendidikan hanya dapat dilakukan oleh orang yang lebih dewasa kepada anak yang belum dewasa. (Ary H Gunawan, 25: 2000). Mendidik dikatakan oleh S. Brodjonegoro dikutip dari Seto Mulyadi memberikan tuntutan kepada manusia yang belum dewasa dalam pertumbuhan dan perkembangan sampai pada kedewasaan jasmani dan rohani.

Berdasarkan latar belakang tersebut, sangat penting untuk dikaji lebih dalam terkait dengan pemenuhan hak anak didik pemasyarakatan di Lembaga Pemasyarakatan Anak, yang ditinjau dari perspektif Hak Asasi Anak. Adapun yang menjadi permasalahan dalam kajian ini, dapat dirumuskan yaitu bagaimana penerapan prinsip terbaik untuk anak dalam pemenuhan hak anak di lembaga pembinaan khusus anak? Tujuan penelitian yaitu menganalisa penerapan prinsip terbaik untuk anak dalam pemenuhan hak anak di lembaga pembinaan khusus anak. Kegunaan penelitian dapat memberikan informasi kepada Lembaga Pembinaan Khusus Anak tentang penerapan prinsip terbaik untuk anak dalam pemenuhan hak anak. Metode Penelitian yang digunakan yuridis-normatif. dengan pendekatan pada peraturan perundang-undangan, serta bersumber pada data sekunder.

\section{Pembahasan}

\section{A. Pembinanan bagi Anak Didik Pemasyarakatan sesuai dengan Hak Asasi Anak}

Pembinaan bagi anak didik pemasyarakatan, diharapkan dapat merubah perilaku, yang bermula tidak baik menjadi lebih baik, dan dalam pembinaan tersebut tetap memperhatikan hak-hak anak. Mengacu kepada teori pembinaan: "The most immediately appealing justification for punishment is the claim that it 
may be used to prevent crime by so changing the personality of the offender that he will conform to the dedicates of law; in word, by reforming him." (Packer, 1988). Pembinaan disini mengarahkan perbaikan narapidana (manusia), bukan kepada perbuatan, karena diharapkan narapidana tidak mengulangi perbuatannya.

Selain pendapat Packer tersebut tersebut di atas, juga Cavadino dan Dignan bahwa "Reform (or rehabilitation) is the idea that punishment can reduce the incidence of crime by taking a form which will improve the individual offender's character or behavior and make him or her less likely to re-offend in future... reform remains a reductivist aim which it may well be right to pursue within a penal system." (Cavadino dan Dignan, 95:1993).

Sedangkan menurut teori rehabilitasi, demi keberhasilan perbaikan perilaku terpidana, maka masing-masing individu sebagai terpidana memerlukan perlakuan sesuai dengan kebutuhannya, sebagaimana diungkapkan oleh Packer, sebagai berikut:

"... the rehabilitative ideal teaches us that we must treat each offender as an individual whose special needs and problems must be known as fully as possible in order to enable us to deal effectively with him. Punishment, in this view, must be forward looking. The gravity of the offense, however measured, may give us a clue to the intensity and duration of the measures needed to rehabilitate; but it is only a clue, not a prescription. There is, then, no generally postulated equivalence between the offense and the punishment, as there would be in the case of the retributive or even the deterrent theory of punishment." (Packer, 1988)

Indonesia dengan mengesahkannya UU No. 12 Tahun 1995 tentang Lembaga Pemasyarakatan dalam Pasal 3 bahwa sistem pemasyarakatan adalah untuk menyiapkan Warga Binaan Pemasyarakatan baik narapidana dewasa maupun bagi anak didik pemasyarakatan. Sistem pemasyarakatan berfungsi agar narapidana tersebut dapat berinteraksi kembali dengan masyarakat secara sehat dan bertanggung jawab.

Begitu juga dalam konstitusi yaitu UUD 1945, Pasal 28 telah menjamin hak asasi setiap warga negaranya termasuk jaminan dan perlindungan hak anak. Oleh karena itu Indonesia mempunyai kewajiban untuk melindungi anak yang 
berhadapan dengan hukum. Hal ini dapat dilihat dengan disahkannya UU No. 11 Tahun 2012 Tentang Sistem Peradilan Anak, dimana UU tersebut mengatur tentang sistem peradilan pidana khusus bagi anak yang berhadapan dengan hukum.

Dengan disyahkannya UU tersebut, untuk memenuhi hak anak didik pemsyarakatan, karena hukum itusifatnya dinamis sehingga hukum harus menyesesuaikan dengan perkembangan yang terjadi di dalam masyarakat. Hal ini sebagaimana pendapat dari Kusumaatmadja bahwa hukum itu harus disesuaikan atau menyesuaikan diri dengan keadaan yang telah berubah. Hal ini disebabkan karena hukum itu tidak hanya mengatur kehidupan manusia dalam masyarakat, tetapi meliputi pula lembaga-lembaga dan proses-proses yang mewujudkan berlakunya kaidah-kaidah dan asas-asas itu dalam kenyataan. (Mochtar Kusumaatmadja, 50:1976).

Terdapat beberapa point yang menjadi bahan pertimbangan yang mengatur tentang perlindungan anak dalam pembentukan hukum, yaitu antara lain:

a. Hukum sebagai sarana dalam pembaharuan masyarakat. Karena hukum merupakan sebagai alat untuk dapat terpeliharanya ketertiban di dalam masyarakat, karena sifatnya memelihara dan mempertahankan yang telah tercapai. Oleh karena iu masyarakat harus mengetahui dan memahami arti dan fungsi hukum itu sendiri.

b. Negara hukum dimana setiap warga negara baik pemerintah sebagai penguasa dan rakyatnya sebagai warga negaranya harus memiliki sikap mental untuk sama-sama mentaati hukum. Pemerintah yang sedang berkuasa tidak dapat sewenang-wenang dalam bertindak dalam ada batasbatas kewenangannya, begitu juga rakyat sebagai warga negara yang baik harus mengetahui hak dan kewajibannya yang telah diberikan kepadanya melalui undang-undang.

c. Dengan pesatnya pertambahan penduduk, ini akan mengalami perubahan pemikiran tentang hukum di dalam masyarakat, dan perkembangan teknologi serta tekanan-tekanan (pressure). Oleh karena itu, hukum sebagai sarana pembaharuan masyarakat, konsepsi yang memiliki kemiripan dengan 
konsepsi law as tool of social engineering yang di poplerkan oleh aliran pragmatic legal realism.

Dengan demikian, sangatlah diperlukan suatu perlindungan anak yang sifatnya memberikan kenyamanan di dalam pelaksanaan perlindungan anak tersebut, dan tentunya disesuaikan dengan perkembangan dinamika hukum yang bersifat dinamis serta mengikuti perkembangan yang terjadi di dalam masyarakat. Hal ini sebagaimana telah diatur dalam Pasal 59 UU Perlindungan Anak, yang mengamanatkan kepada pemerintah dan lembaga negara lainnya untuk melaksanakan kewajiban dan bertanggung jawab memberikan perlindungan khusus, terutama kepada anak yang berhadapan dengan hukum, baik anak-anak yang berkonflik dengan hukum artinya sebagai pelaku tindak pidana maupun anak sebagai korban tindak pidana.

Terkait hal tersebut, menurut (Barda Nawawi Arief dan Muladi, 55:2012), bahwa pendekatan khusus dalam menangani anak atau remaja yang berhubungan dengan hukum antara lain, "Anak yang melakukan tindak pidana/kejahatan (juvenile offender) janganlah dipandang sebagai seorang penjahat (criminal), tetapi harus dilihat sebagai orang yang memerlukan bantuan, pengertian dan kasih saying". Kemudian pendekatan secara yuridis harus lebih mengutamakan pendekatan persuasive-edukatif dan pendekatan kejiwaan (psikologis), ini berarti menghindari :

a. Proses hukum yang bersifat menghukum yang bersifat degradasi mental dan penurunan semangat (discouragement).

b. Proses stigmatisasi yang dapat memperhambat proses perkembangan, dan kematangan serta kemandirian anak dalam arti yang wajar.

Oleh karena itu, beberapa UU yang telah disahkan oleh pemerintah semua itu dipertimbangkan untuk kepentingan masa depan anak yang berkonflik dengan hukum. UU tersebut yaitu UU No. 12 tahun 1995 tentang Pemasyarakatan, UU No. 23 tahun 2002 tentang Perlindungan Anak, UU No. 35 tahun 2014 tentang Perubahan atas UU No. 23 tahun 2002. UU tersebut merupakan peraturan pelaksana dari UUD 1945 dalam Pasal 28C ayat (1) bahwa 
setiap orang berhak mengembangkan diri melalui pemenuhan kebutuhan dasarnya, berhak mendapat pendidikan dan memperoleh manfaat dari ilmu pengetahuan dan teknologi, seni dan budaya, demi meningkatkan kualitas hidupnya dan demi kesejahteraan umat mausia. (UUD NRI 1945)

Untuk mentaati setiap peaturan khususnya dalam perlindungan terhadap anak-anak Indonesia yang berkonflik dengan hukum, dalam rangka memberikan tanggungjawab pemerintah untuk memberikan pemenuhan hak anak didik pemasyarakatan di Lembaga Pemasyarakatan, maka Pemerintah Indonesia mengeluarkan Kepres No. 36 Tahun 1990, mewajibkan untuk menaati setiap aturan yang ada terkait dengan perlindungan anak-anak Indonesia, termasuk pemenuhan hak anak didik pemasyarakatan sebagai anak yang berkonflik dengan hukum. Kepres tersebut merujuk kepada Convention on the Rights of the Child.

Perlindungan terhadap anak atau remaja yang kehilangan kebebasan berdasarkan peraturan PBB bahwa anak atau remaja yang kehilangan kebebasannya mempunyai hak memperoleh pendidikan, latihan keterampilan dan latihan kerja, rekreasi, memeluk agama, mendapatkan perawatan kesehatan, peberitahuan tentang kesehatan, berhubungan dengan masyarakat luas. (Waluyadi, 26:2009). Berdasarkan ketentuan tersebut, Indonesia sudah seharunya menaati setiap aturan terkait dengan konvensi tersebut, salah satu yang terpenting di dalamnya adalah prinsip the best interest of the child. Pendekatan prinsip the best interest of the child menurut Yayasan Pemantau Hak Anak (Children Human Right: Foundation) didasari tiga faktor yaitu (Abintoro Prakoso, 45:2013):

Anak diasumsikan belum mempunyai legal capacity untuk melakukan tindak pidana mengingat kondisi dan sifatnya yang masih tergantung pada orang dewasa, tingkat usia perkembangan fisik, mental, moral dan spiritualnya belum matang;

1. Anak dianggap belum mengerti secara sungguh-sungguh atas kesalahan yang telah mereka perbuat, sehingga sudah sepantasnya diberi pengurangan 
hukuman serta pembedaan pemberian hukuman bagi anak-anak dengan orang dewasa atau bahkan dialihkan ke jalur non yuridis

2. Bila dibandingkan dengan orang dewasa, anak-anak diyakini lebih mudah dibina dan disadarkan.

Adapun The Beijing Rules mengatur tentang:

1. Tujuan pelatihan dan pembinaan anak di Lembaga Pemasyarakatan adalah untuk perawatan dan perlindungan, pendidikan dan keahlian kejuruan dengan tujuan untuk membantu mereka memahami aturan yang konstruktif dan produktif secara social di dalam masyarakat (rule 26.1)

2. Anak-anak dalam Lembaga pemasyarakatan hendaknya menerima perawatan, perlindungan dan semua kebutuhan bantuan sosial, pendidikan, kejuruan, psikologis, medis dan fisik yang mereka butuhkan menurut usia, jenis kelamin dan kepribadian mereka serta menurut perkembangan mereka secara menyeluruh (rule 26.2)

3. Anak-anak dalam Lembaga pemasyarakatan hendaknya dipisahkan dari orang dewasa (Rule 26.3)

4. Anak perempuan yang ditempatkan di Lembaga pemasyarakatan berhak atas perhatian khusus menurut kebutuhan dan masalah pribadi mereka. Tidak ada alasan bagi mereka menerima lebih sedikit perhatian, bantuan perlindungan, perlakuan dan pelatihan dibandingkan anak laki-laki sebagai pelaku pelanggaran (Rule 26.4).

5. Anak berhak dikunjungi oleh orang tua atau walinya di Lembaga pemasyarakatan (Rule 26.5)

6. Kerjasama antar kementerian dan Lembaga hendaknya dijalin untuk tujuan menyediakan pelatihan akademik atau kejuruan jika perlu untuk anak-anak yang ditahan, dengan tujuan menjamin bahwa mereka tidak meninggalkan Lembaga pemasyarakatan dengan kerugian dari segi pendidika (Rule 26.6). Asas dalam melaksanaan pembinaan warga binaan termasuk anak didik pemasyarakatan berdasarkan Pasal 2 Undang Undang No. 12 tahun 1995 tentang Pemasyarakatan yang merupakan pedoman bagi Pembina di LAPAS yaitu asas pengayoman, asas persamaa perlakuan dan pelayanan, asas pendidikan, asas 
pembimbingan, asas penghormatan harkat dan martabat, asas kehilangan kemerdekaan merupakan satu-satunya penderitaan, asas terjaminnya hak untuk tetap berhubungan dengan keluarga dan orang-orang tertentu. Oleh karena itu upaya melakukan perubahan tingkah laku anak didik pemasyarakatan dengan melalui proses pembinaan, pembimbingan dan perlindungan terhadap hak-hak anak didik pemasyarakatan.

Dalam Pasal 82 ayat (1) butir e UU No. 11 Tahun 2012 tentang Sistim Peradilan Pidana Anak : “Tindakan yang dapat dikenakan kepada anak adalah kewajiban mengikuti pendidikan formal dan/atau pelatihan yang diadakan oleh pemerintah atau badan swasta", sedangkan dalam UU No. 23 tahun 2002 tentang Perlindungan Anak menyebutkan : "LAPAS Anak merupakan tempat pendidikan anak bukan penghukuman anak", dan dalam Pasal 84 "anak yang ditahan di Lembaga Penempatan Anak Sementara (LPAS) masih dalam proses adjudikasi".

Pada tahap ini, anak berhak untuk memperoleh yang menjadi haknya yaitu untuk mendapatkan pelayanan, perawatan, pendidikan dan pelatihan, pembimbingan dan pendampingan, Oleh karena itu pemerintah melalui LAPAS dengan pengawasan BAPAS untuk melaksanakan kewajibannya sebagaimana telah diamanatkan melalui UU.

Begitu juga dalam penahanan selama proses dilakukan untuk kepentingan penyidikan/penuntutan/pemeriksaan di sidang pengadilan sebagai mana dalam UU Pasal 33, 34, 35, mengamanatkan anak apa yang menjadi kebutuhannya baik jasmani, rohani dan sosial anak harus terpenuhi.

Adapun Pasal 85 menjelaskan bahwa anak yang dijatuhi pidana penjara ditempatkan di Lembaga Pembinaan Khusus Anak (LPKA) berhak memperoleh pembinaan, pembimbingan, pengawasan, pendampingan, pendidikan dan pelatihan, serta hak-hak lain sesuai dengan peraturan perundang-undangan dengan pengawasan oleh BAPAS. Dalam pemberikan hak tersebut, tetap diperhatikan pembinaan anak yang bersangkutan antara lain mengenai pertumbuhan dan perkembangan anak, baik fisik, mental dan sosial. Oleh karena itu latar belakang sosial ekonomi, psikologis dan lain-lain anak didik 
pemasyarakatan, lingkungan dan situasi pembinaan dilakukan perlu diperhatikan sehingga dalam melaksanaan pembinaan tidak mengalami hambatan. Dengan demikian pembina harus mampu merubah cara berpikir peserta anak didik, untuk tidak terpengaruh pada situasi tetapi menguasai situasi sehingga materi pembinaan dapat terserap dengan baik maka petugas kemasyarakatan harus mengetahui kebutuhan, karakter, tingkat kematangan, emosi, logika masingmasing individu anak dengan prinsip the best interest of the child dalam melaksanaan pembinaan anak didik pemasyarakatan di LAPAS. Dalam PP No. 31 Tahun 1999 tentang Pembinaan dan Pembimbingan Warga Binaan Pemasyarakatan dinyatakan bahwa pelaksanaan pembinaan anak didik pemasyarakatan dilakukan oleh Pembina Pemasyarakatan (Pasal 15 ayat 1) dan disediakan sarana dan prasarana yang dibutuhkan (Pasal 16).

Pemidanaan di LPKA sampai batas umur mencapai 18 tahun, apabila belum selesai menjalani pidana di LPKA maka dipindahkan ke Lembaga Pemasyaraakatan Pemuda dan apabila masih belum selesai menjalani masa pidananya dipindahkan ke Lembaga Pemasyarakatan dewasa dengan memperhatikan kesinambungan pembinaan.. Dalam perlindungan dan pemenuhan hak anak didik pemasyarakatan melalui pembinaan khusus di LPKA maka harus diperhatikan kepentingan terbaik untuk anak karena anak sebagai subjek dengan kebutuhan khusus dan mempunyai masa depan. Hak anak yang terpenting hak memperoleh pendidikan. Oleh karena itu bahwa Lapas mempunyai tanggungjawab untuk melaksanakan pendidikan dan penpajaran serta menyedian sarana dan prasarana lain untuk mendukung proses pelaksanaan Pendidikan tersebut. Sebagai dasar hukum dari pelaksanaan Pendidikan tersebut yaitu Pasal 9 dan 10 PP No. 32 tahun 1999 tentang Syarat dan tata Cara Pelaksanaan Hak Warga Binaan Pemasyarakatan.

Sebagai salah satu upaya lain dalam rangka memberikan perlindungan dan pemenuhan hak anak didik pemasyarakatan, Kementerian Hukum dan HAM melalui Direktorat Jenderal Pemasyarakatan telah memproklamrkan piagam Arcamanik dengan hasil ada 10 prinsip dalam Pembinaan Anak. Piagam ini merupakan hasil perumusan Konferensi yang diadakan di Lembaga 
Pemasyarakatan Anak di Bandung, 10 prinsip pembinaan anak tersebut tentang perubahan system perlakuan terhadap anak berhadappan dengan hukum yang ramah berbasis budi pekerti.

Piagam Arcamanik yang berisi 10 Prinsip Pembinaan Anak yang berhadapan dengan hukum (Direktorat Jenderal Pemasyarakatan, 10 Prinsip Pembinaan Anak Piagam Arcamanik), yaitu:

1. Anak adalah amanah Tuhan YME, generasi penerus bangsa wajib mendapatkan kesempatan yang seluas-luasnya untuk dapat tumbuh dan berkembang secara optimal;

2. Penahanan dan penjatuhan pidana penjara bagi anak merupakan upaya terakhir dan dilakukan paling singkat dengan memperhatikan kepentingan terbaik bagi anak;

3. Tujuan system pembinaan dan pembimbingan anak adalah keadilan restroratif berbasis budi pekerti;

4. Pemberian pidana penjara bukan merupakan bentuk balas dendam dari Negara;

5. Selama menjalankan pembinaan dan pembimbingan tidak boleh diasingkan dari keluarga dan masyarakat;

6. Dalam proses pembinaan dan pembimbingan anak berhak mendapat perlindungan dari kekerasan dan segala bentuk diskriminasi lainnya sesuai dengan harkat dan martabat kemanusiaan;

7. Pendidikan merupakan intisari pembinaan dan pembimbingan bagi anak dalam rangka meningkatkan kecerdasan intelektual, emosional dan spiritual, pengembangan potensi diri serta pelatihan keterampilan dalam upaya pengembangan minat dan bakat;

8. Pembinaan dan pembimbingan anak wajib diarahkan untuk segera mungkin dikembalikan kepada keluarga dan masyarakat dalam bentuk program asimilasi dan integrasi;

9. Negara menjamin perlindunngan dan pemenuhan hak-hak anak melalui penyediaan sumber daya dana sarana prasarana yang ramah anak; 
10. Pembinaan dan pembimbingan terhadap anak dilaksanakan secaraa sinergi antara pengasuh, pembimbing kemasyarakatan, keluarga dan masyarakat.

Dengan adanya perubahan sistim perlakuan ramah anak berbasis budi pekerti, dapat dilaksanakan dengan melakukan pendampingan pada saat di LPKA, kemudian dapat dilakukan pengenalan diri dan lingkungan, serta pengenalan program pembinaan, pengasuhan pemasyarakatan sampai pada tahap mempersiapkan reintegrasi sosial anak. Meskipun dalam pelaksanaannya setiap Lapas tentunya akan berbeda-beda, hal ini bergantung kepada konsisi dan situasi Lapas masing-masing wilayah.

Misalnya, oleh (Nurini Aprilianda, 2014 dalam laporan akhir pengkajian hukum tentang model pembinaan anak berbasis pendidikan layak anak dalam sistem pemasyarakatan), bahwa Pendidikan formal belum dilaksanakan oleh semua LPKA karena terbatasnya jumlah anak yang memenuhi persyaratan mengikuti pendidikan, khususnya lama pidana, minat anak yang rendah terhadap pendidikan, fasilitas dan sarana pendukung yang minim dan rendahnya dukungan dari sekolah si anak sebelumnya, adapun LPKA yang menyelenggarakan pendidikan formal berjalan cukup baik seperti LPKA pria Tangerang dan LPKA Medan serta LPKA Bandung, sedangkan LPKA yang lain, lebih banyak menyelenggarakan program pendidikan kesetaraan seperti paket $\mathrm{A}$, paket $\mathrm{B}$, paket $\mathrm{C}$ dan pendidikan keterampilan seperti menjahit, melukis, elektronik, percetakan dan lainnya..

Program pembinaan dan pembimbingan LPKA di Tangerang yang wajib diikuti anak didik pemasyarakatan berbentuk: (Fransiska Novita Eleanor dan Esther Masri, 2018)

1. pendidikan formal dan non formal, LPKA Pria Tangerang melaksanakan Paket A, Paket B, Paket C dan pelatihan bengkel, automotive, pelatihan cukur rambut, pertukanagan, pertanian dan perkebunan

2. Pembinaan keagamaan dan konseling yang bertujuan perbaikan diri anak, ruang terbuka bagi anak yang memerlukan adanya perhatian lebih banyak sehingga pihak terkait mengakomodir hal tersebut atau diikuti oleh kegiatan keagamaan. 
3. Mewujudkan ramah anak, perubahan nama Lembaga Pemasyarakatan Anak (Lapas Anak) berubah nama menjadi LPKA Tangerang sehingga pendekatan anak lebih menekankan kepada ramah dan layak anak. Perlakuan sistem terhadap ramah anak di aplikasikan seperti pendampingan, pengenalan terhadap diri sendiri dan lingkungan.

Pembinaan terhadap anak di LPKA Salemba berupa Paket B, kegiatan Konseling dan Penyuluhan, kegiatan inkluisi social, pembinaan rohani, Pramuka, Pembinaan Jasmani, Layanan perpustakaan, Pusteling, kegiatan seni, upacara hari Senin, sedangkan pembinaan di LPKA Bandung berbentuk: (Yulianto dan Yul Ernis, 2016)

1. Pembinaan mental rohani, anak didik beragama Islam wajib mengikuti di pesantren Miftahul Jannah, sedangkan yang beragama Kristen setiap hari Jumat didatangkan pendeta, kerjasama dengan HKBP, BKPFKK.

2. Pembinaan intelektual dan wawasan kebangsaan, diadakan kursus-kursus yang diselenggrakan atas kerjasama dengan LSM maupun partisipan yang pedulianak antara lain kursus Bahasa Inggris, pelatihan menulis artikel dan lain-lain.untuk wawasan kebangsaan melalui Pramuka bekerjasama dengan Gugus Dharma Sukamiskin Kwartir Arcamanik, LAHA, LPA, LKKS, Ombudsman, BP3AKB, UPI, UNPad, ITB dan lain-lain .

3. Pembinaan olahraga dan seni, kegiatan rutin setiap hari dilakukan senam pagi, futsal, bulutangkis, tenismeja dan music, nasyid, marawis, drumband, angklung, band dan lain-lain.

4. Pembinaan kemasyarakatan/social, mengikuti acara di luar LPKA yang diselenggarakan oleh mitra/LSM dan instansi luar melalui program asimilasi, cuti menjelang bebas, pelepasan bersyarat.

5. Pembinaan kemandirian, pelatihan keterampilan yaitu menjahit, peternakan, montir/bengkel motor dan mobil, pertamanan, perikanan, gunting rambut, pembuatan kerajinan anak-anak dan lain-lain.

6. Peredaran uang, di LPKA Bandung diterapkan program Bebas Peredaran Uang (BPU) yaitu bahwa segala sesuatu yang mentangkut segi keuangan 
anak didik (keluar/masuknya uang) semuanya akan dicatat dan disimpan dalam bentuk buku tabungan.

Berdasarkan contoh LPKA di atas program pembinaan dan pembimbingan sudah dilaksanakan oleh LPKA walaupun bentuk dan program pembinaan dan pembimbingan bermacam-macam, Prinsip terbaik untuk anak sudah diakomodir LPKA dengan program pembinaan dan pembimbingan tetapi ada yang sudah optimal dan ada yang belum optimal, disebabkan karena berbagai faktor.

\section{Penutup}

\section{A. Kesimpulan}

Salah satu ciri prnsip terbaik untuk anak tercermin dalam diwajibkannya pendidikan bagi anak yang berkonflik dengan hukum dalam LPKA baik pendidikan formal maupun pendidikan informal sehingga hak pendidikan terpenuhi.

Pelaksanaan perlindungan anak yang berkonflik dengan hukum dengan menggunakan prinsip terbaik untuk anak. LPKA belum dilaksanakan secara optimal karena LPKA belum semuanya melaksanakan program pembinaan secara efektif dan efisien serta sesuai dengan peraturan perundang-undangan yang berkaitan dengan anak yang berkonflik dengan hukum.

\section{B. Saran}

Oleh karena itu perlu didesain ulang model dan program pembinaan dan pembimbingan di LPKA termasuk sarana dan prasarananya disesuaikan dengan kebutuhan anak, di samping memperhatikan latar belakang anak, dan memperhatikan lingkungan dimana pembinaan dilakukan sehingga hak asasi anak dapat terpenuhi.

\section{Daftar Pustaka}

Aprilianda, Nurini. Laporan Akhir Pengkajian Hukum tentang Model Pembinaan Anak Berbasis Pendidikan Layak Anak dalam Sistem 
Pemasyarakatan. Jakarta: Badan Pembinaan Hukum Nasional, Kementerian Hukum dan HAM RI, 2014

Cavadino, Michael \& James Dignan, The Penal System. London: Sage Publication, 1993.

Darmodihardjo dan Sidharta, Pokok-Pokok Filsafat Hukum. Jakarta: Gramedia Pustaka, 2006.

Fransiska Novita Eleanor dan Esther Masri, "Pembinaan Khusus Anak Menurut

Sistem Peradilan Anak", Jurnal Kajian Ilmiah, Vol. 18, No. 3, September 2018.

Gunawan, Ary H, Sosiologi Pendidikan. Jakarta: Rineka Cipta, 2000.

Suartha, I Dewa Made, Pengkajian Hukum Lembaga Penempatan Anak Sementara, Jakarta: BPHN, 2013.

Kusumaatmadja, Mochtar, Hukum, Masyarakat dan Pembinaan Hukum Nasional. Bandung: Lembaga Kriminologi Universita Padjajaran, 1976

Muladi dan Barda Nawawi Arief, Bunga Rampai Hukum Pidana. Bandung: Alumni, 2012.

Packer, L. Herbert. The Limit of the Criminal Sanction. California: Stanford University Press, 1988.

Prakoso, Abintoro, Pembaharuan Sistem Peradilan Pidana Anak, Jakarta: Laksbang Grafika, 2013.

Waluyadi, Hukum Perlindungan Anak, Bandung: Mandar Maju, 2009

Yulianto dan Yul Ernis, Lembaga Pembinaan Khusus Anak danlam Perspektif Sistem Peradilan Pidana Anak, Jakarta: BPHN, 2016.

Republik Indonesia, Undang-Undang Nomor 12 Tahun 1995 Tentang Lembaga Pemasyarakatan. Lembaran Negara Tahun 1995 Nomor 77. Tambahan Lembaran Negara Nomor 3614.

Direktorat Jenderal Pemasyarakatan. "Inilah 10 Prinsip Pembinaan Anak Piagam Arcamanik" (http://www.ditjenpas.go.id/inilah-10-prinsip-pembi naan-anak-piagam-arcamanik), diunduh pada Januari 2020.

Halim, Devina. "Kasus Anak Berhadapan dengan Hukum Tertinggi, Didominasi Kejahatan Seksual” (https://nasional.kompas.com/read/2019/01/08/193 81211/kasus-anak-berhadapan-dengan-hukum-tertinggi-didominasi-keja hatan-seksual), diakses pada Januari 2020. 